\title{
PKM KARYAWAN OBJEK WISATA BUKIT TINTINGON RURUKAN
}

\author{
Sanerita Tresnawaty Olii \\ Fakultas Bahasa dan Seni, Universitas Negeri Manado
}

ABSTRAK

Pemanfaatan potensi alam untuk menjadi daya tarik suatu objek wisata membawa dampak positif bagi kesejahteraan masyarakat. Hal ini ditandai dengan bertambahnya lapangan pekerjaan dan ekonomi masyarakat yang meningkat. Dengan demikian diperlukan SDM yang mampu berbahasa Inggris dengan baik dan benar, terutama untuk berkomunikasi dengan turis mancanegara. Pengabdian IbM ini dilakukan dengan tujuan untuk mengatasi permasalahan kurangnya kemampuan karyawan dalam berbahasa Inggris dengan mengadakan pelatihan Bahasa Inggris bagi karyawan objek wisata Bukit Tintingon. Pelatihan ini bertujuan untuk memberikan pengalaman berbahasa Inggris, karena itu digunakan metode drill and repetition, roleplay, dan diskusi serta ceramah. Metode-metode ini merupakan metode yang efektif dalam pembelajaran bahasa. Pada pelatihan ini kelompok Mitra telah dilatih menggunakan bahasa Inggris, para karyawan mendapat kesempatan untuk mempraktekkan apa yang telah dipelajari melalui metode drill and repetition. Diakhir pelatihan dilakukan monitoring pendampingan aplikasi penggunaan bahasa Inggris oleh para karyawan peserta pelatihan ketika menghadapi wisatawan asing

Kata kunci: drill and repetition, roleplay, mitra 


\section{PENDAHULUAN}

\section{Analisis Situasi}

Menurut Pendit (1990), pariwisata adalah salah satu jenis industry baru yang mampu menghasilkan pertumbuhan ekonomi yang cepat dalam penyediaan lapangan kerja, peningkatan penghasilan, standar hidup serta menstimulasi sektorsektor produktivitas lainnya.

Keindahan alam suatu tempat sangatlah berperan penting dalam pengembangan sektor pariwisata. Saat ini telah terdapat banyak tempat yang diekspos sebagai objek wisata alam. Menurut SK MENPARPOSTEL

No.:

KM.98/PW.102/MPPT-87, Objek Wisata adalah semua tempat atau keadaan alam yang memiliki sumber daya wisata yang dibangun dan dikembangkan sehingga mempunyai daya tarik dan diusahakan sebagai tempat yang dikunjungi wisatawan. Propinsi Sulawesi Utara merupakan salah satu daerah yang memiliki keindahan alam yang bernilai tinggi dan jarang ditemukan di daerah lain. Salah satu tempat yang berpotensi menjadi objek wisata yaitu Kelurahan Rurukan, Tomohon. Para pengunjung dapat menikmati indahnya pemandangan dari Bukit Tintingon sambil menikmati berbagai kuliner yang ada. Terdapat juga pertunjukkan Tarian Kabasaran yang dilakukan.

Karyawan yang dipekerjakan di objek wisata ini berasal dari Kelurahan Rurukan. Pengawas, Petugas Pos masuk, resepsionis, karyawan administrasi, sekuriti, sampai kepada tukang kebun dan pekerja konstruksi bangunan yang dipekerjakan di tempat ini berasal dari penduduk Rurukan di sekitar objek wisata. Bahkan para penjual kuliner dan penari Kabasaran yang ada, semuanya berasal dari kelurahan Rurukan.

Permasalahan yang ada, terlihat pada kebutuhan para karyawan bersebut akan pembekalan kemampuan berbahasa Inggris pada saat berhadapan dengan turis mancanegara. Selain berbicara, mereka juga harus mampu bercerita tentang keberadaan Bukit Tintingon serta berbagai hal yang dapat dinikmati di objek wisata ini. Dari penjelasan ini, focus pengabdian ini terletak pada peningkatan kemampuan berkomunikasi dalam bahasa Inggris bagi karyawan dengan menyediakan pelatihan dan sertifikat.

Sebagai mitra dalam kegiatan pengabdian ini adalah kelompok karyawan Objek Wisata Bukit Tintingon yang terdiri dari 15 orang. Dampak keberadaan mitra terhadap lingkungan kerjanya adalah peningkatan pengetahuan dan keterampilan berbahasa Inggris dengan menggunakan metode Drill dan Repetition, dengan metode ini pembelajaran bahasa Inggris diulang-ulang hingga target dapat tercapai.

\section{Permasalahan Mitra}

Selama ini masalah yang dihadapi oleh para karyawan di Bukit Tintingon adalah bagaimana meningkatkan kemampuan Bahasa Inggris mereka agar dapat menyambut dan melayani pengunjung mancanegara dengan baik. Terdapat beberapa alasan mengapa pelatihan kemampuan berbahasa Inggris perlu dilakukan bagi para karyawan:

1. Pengalaman belajar Bahasa Inggris para karyawan masih rendah karena Latar belakang belajar mereka masih minim. Kebanyakan karyawan merupakan lulusan Sekolah Menengah Atas sehingga kemampuan bahasa Inggris mereka sebatas yang mereka pelajari di sekolah.

2. Belum ada tim pengabdi yang membantu dalam hal peningkatan kemampuan berbahasa Inggris bagi masyarakat sekitar, sehingga ketika mereka dipekerjakan di objek wisata ini, kemampuan bahasa Inggrisnya belum memadai.

3. Praktek berbicara dan bercerita dalam bahasa Inggris masih sangat rendah sehingga perlu adanya praktek dan panduan khusus untuk hal tersebut.

4. Budaya para karyawan sangat berbeda dengan budaya para turis mancanegara sehingga selain bahasa, pemahaman tentang budaya yang menyertai penggunaan bahasa Inggris perlu dipahami melalui pelatihan bahasa Inggris.

Dari permasalahan yang dihadapi mitra yang telah dipaparkan di atas, maka pelaksana IbM dan mitra telah menentukan prioritas yang harus ditangani, yaitu:

1. Peningkatan kemampuan Bahasa Inggris bagi karyawan objek wisata 
Bukit Tintingon, khususnya mereka yang bertugas melayani pengunjung secara langsung.

2. Pembuatan panduan yang praktis dan efisien untuk praktek berbicara dan bercerita dalam bahasa Inggris bagi para karyawan.

3. Perealisasian peningkatan Bahasa Inggris pada karyawan objek wisata Bukit Tintingon dengan metode yang tepat dan menarik.

4. Penjelasan tentang budaya yang menyertai penggunaan bahasa Inggris.

\section{TARGET LUARAN}

Target luaran dari kegiatan IPTEKS bagi Masyarakat bagi karyawan objek wisata Bukit Tintingon Rurukan sebagai berikut:

1. Artikel Ilmiah

2. Adanya peningkatan penguasaan dan keterampilan berbahasa Inggris oleh para karyawan di objek wisata Bukit Tintingon dengan menggunakan metode Drill dan Repetition, Roleplay and Discussion.

\section{METODE PELAKSANAAN}

Pelatihan ini menggunakan metode drill and repetition, role play, diskusi, ceramah dan evaluasi. Drill dan Repetition merupakan metode yang telah digunakan dalam melatih para karyawan dalam berbicara dan melakukan percakapan dalam bahasa Inggris. Roleplay merupakan metode yang digunakan untuk memberikan pengalaman bagi para karyawan berada pada suatu situasi yang berbeda sesuai dengan situasi yang mungkin dialami dalam pekerjaan yang membutuhkan percakapan dalam bahasa Inggris. Dalam metode ini, para karyawan mendapat kesempatan untuk mempraktekkan apa yang telah dipelajari melalui metode drill and repetition. Dalam peningkatan pemahaman lintas budaya digunakan metode ceramah dan diskusi. Selanjutnya metode evaluasi merupakan metode yang digunakan untuk mengukur kemampuan berbicara para karyawan setelah mengikuti pelatihan. Tahap yang terakhir, pengabdi melakukan monitoring pendampingan aplikasi penggunaan bahasa Inggris oleh para karyawan peserta pelatihan ketika menghadapi wisatawan asing.

Berikut ini merupakan tahapan yang dilaksanakan:

Tahap I : Melakukan observasi untuk mengetahui fokus permasalahan yang paling urgen untuk ditetapkan dalam rencana IbM, yaitu pelatihan.

(Telah dilakukan)

Tahap II : Menetapkan kelompok Mitra yang akan diikutsertakan dalam pelatihan. (Telah dilakukan)

Tahap III: Menyusun proposal kegiatan IbM Karyawan Objek Wisata Bukit Tintingon, Rurukan. (Telah dilakukan)

Tahap IV: Jika proposal disetujui untuk dilaksanakan, maka akan ditindaklanjuti dengan pelaksanaan pelatihan untuk kelompok Mitra.

Tahap V: Tahap persiapan sebelum pelatihan.

Penyusunan jadwal pelatihan sesuai dengan fokus permasalahan yang disepakati bersama kelompok Mitra. Jadwal pelatihan sesuai dengan kesepakatan.

Persiapan meliputi:

1. Persiapan materi pelatihan bahasa Inggris

2. Penyusunan jadwal pertemuan untuk pelatihan

3. Pengadaan alat tulis peserta dan kamus sebagai penunjang kegiatan pelatihan.

TAHAP VI : Pelaksanaan Pelatihan dengan jadwal yang sudah disepakati.

Pelatihan dilaksanakan selama 4 minggu dengan jadwal pertemuan dua kali seminggu selama 8 kali pertemuan. Dengan peserta direncanakan sebanyak 15 orang.

TAHAP VI : Evaluasi

TAHAP VII : Tindak Lanjut berupa pendampingan

Dalam kegiatan pengabdian masyarakat ini, kelompok Mitra ikut 
berpartisipasi dalam pelaksanaan program. Partisipasi Mitra terlihat pada:

1. Berpartisipasi dalam penyampaian permasalahan yang dihadapi oleh kelompok Mitra dalam menjalankan tugas sebagai karyawan pada objek wisata.

2. Berpartisipasi dalam identifikasi masalah yang paling urgen.

3. Ikut serta dalam menentukan jadwal pelatihan yang dilakukan.

4. Pihak Pengelola memberikan izin bagi karyawannya untuk mengikuti program pelatihan bahasa Inggris.

\section{HASIL DAN PEMBAHASAN}

Hasil yang sudah dicapai dalam pengabdian Ipteks bagi Masyarakat (IbM) adalah:

1. Kegiatan koordinasi serta observasi telah dilakukan di obyek wisata tempat pelaksanaan kegiatan pengabdian. Kegiatan ini telah dilakukan dengan pihak pengelola. Melalui wawancara dengan pihak pengelola diperoleh informasi tentang kemampuan berbahasa Inggris para karyawan yang ada. Selama ini para karyawan hanya mengandalkan tourist guide yang menyertai wisatawan sehingga bagi wisatawan tanpa tourist guide kurang terlayani di objek wisata ini. Para karyawan dengan kemampuan berbahasa Inggris yang sangat minim, cenderung menghindari berdialog langsung dengan wisatawan asing yang berkunjung. Hasil koordinasi dengan pihak pengelola, disepakati kegiatan dilaksanakan di ruangan yang ada dengan fasilitas yang dianggap memenuhi syarat untuk pelaksanaan pelatihan.

2. Persiapan Pelatihan

Dalam persiapan pelatihan, pelaksana menyiapkan materi pelatihan dengan memperhatikan kebutuhan para karyawan. Materi yang dipersiapkan bagi pelatihan ini antara lain tentang: Opening and Closing a Conversation, Courtesy, Greetings, Numbers, Asking Help, Question Words, Asking and
Answering Questions, and Changing Money.

3. Pelaksanaan

Pelaksanaan pelatihan ini diawali dengan proses pelatihan dalam ruangan. Para karyawan dilatih menggunakan ungkapanungkapan bahasa Inggris yang berkaitan erat dengan pariwisata. Kemudian dilakukan praktek yang membantu para karyawan berdialog dengan wisatawan asing dengan pendampingan.

4. Hasil Pelatihan

Selama proses pelatihan, pelaksana kegiatan pengabdian melakukan pemantauan kepada peserta latihan sekaligus melakukan pendampingan dalam praktek. Wawancara tentang materi dan metode pelatihan juga dilakukan. Secara umum pelatihan ini sangat baik karena materi yang disajikan sesuai dengan kebutuhan.

\section{KESIMPULAN}

Kegiatan pengabdian Ipteks bagi Masyarakat (IbM) sudah dilaksanakan dalam bentuk pelatihan bahasa Inggris bagi karyawan objek wisata. Pelatihan diawali dengan pelatihan dalam kelas yang dilanjutkan dengan praktek yang didampingi pelaksana.

Melalui wawancara dan diskusi pelaksana dengan pengelola dan peserta pelatihan, mereka mengharapkan pelatihan serupa dilakukan dalam waktu yang lebih lama lagi agar mereka dapat dilatih lebih baik lagi.

\section{REFERENSI}

Pendit, Nyoman S, 1990. Ilmu Pariwisata: Sebuah Pengantar Perdana. UPT

Perpustakaan UM-Universitas Negeri Malang.

Saragih, Sabastian. 1993. Membedah Perut L.S.M. Pustaka Pembangunan Swadaya

Nusantara.

Silberman, Mel. 1996. Active Learning: 101 Strategi Pembelajaran Aktif. Yogyakarta: Pustaka Insan Madani https://id.m.wikipedia.org/wiki/obyek wis ata . Diakses 20161212 